ditioned reflex (Dekker and Groen, 1956; McFadden et al., 1969).

There is some contradiction in the literature on the clinical effects of disodium cromoglycate (Pepys et al., 1968; Herxheimer and Bewersdorff, 1969), but nearly all authors are agreed that it often gives useful subjective relief not always reflected by changes in the $\mathrm{FEV}_{1}$, the most common index used. Improvements in asthma need not always be reflected in the $\mathrm{FEV}_{1}$ (Woolcock and Read, 1965; Lane, 1969). Two authors state that the response to treatment by disodium cromoglycate cannot be predicted on allergic grounds alone (Campbell and Tandon, 1969; Ford, 1969). Its benefit in a specific case still appears to be unpredictable.

It is postulated that disodium cromoglycate can interfere with exacerbations of asthma which are emotional in nature brought about by hyperventilation consequent on the proprioceptive perception of asthma or other emotional cause, in addition to blocking the results of reagin-antigen union with its consequent asthma. Either mode of action may be at work separately or together at the same time. When an active allergic reaction is present both subjective and objective relief would be obtained. Otherwise the emotional exacerbations caused by hyperventilation together with the relief of postexercise asthma would give considerable subjective symptomatic and functional relief not necessarily reflected in periodical measurements of ventilatory capacity in the outpatient department. Indications for the use of disodium cromoglycate are still not definite, and it is suggested that one simple test indicating its use would be to observe whether a fall in the ventilatory capacity followed two minutes of maximum hyperventilation.

This work was partly supported by a grant-in-aid from the Asthma Foundation of Tasmania. My thanks are due to Professor A. Baikie and Dr. Alastair Campbell for critical encouragement, and to Mr. Peter Guilfoyle and Dr. A. Grassio for their help with the statistical analysis.

\section{References}

Altounyan, R. E. C. (1967). Acta Allergologica, 22, 487.

Campbell, A. H., and Tandon, M. K. (1969). Medical fournal of Australia, 2, 535 .

Clarke, P. S. (1970). Medical fournal of Australia, 1, 535.

Cox, J. S. G. (1967). Nature, 216, 1328.

.

Curry, J. J. (1947). Fournal of Clinical Investigation, 26, 430

Davies, S. E. (1968). British Medical fournal, 3, 593.

Dekker, E., and Groen, J. (1956). Fournal of Psychosomatic Research, 1, 58. Ford, M. R. (1969). Medical fournal of Australia, 2, 537.

Herxheimer, H., and Bewersdorff, H. (1969). British Medical fournal, 2, 220.

Howell, J. B. L., and Altounyan, R. E. C. (1967). Lancet, 2, 539.

Lane, D. J. (1969). British Medical fournal, 4, 710.

Lendrum, A. C. (1944). Fournal of Pathology and Bacteriology, 56, 441.

McFadden, E. R., jun., Luparello, T., Lyons, H. A., and Bleecker, E. (1969). Psychosomatic Medicine, $31,134$.

Newhouse, M. T., Becklake, M. R., Macklem, P. T., and McGregor, M. (1964). Fournal of Apolied Physiology, 19, 745.

Pepys, J., Hargreave, F. E., Chan, M., and McCarthy, D. S. (1968). Lancet, $2,134$.

Smith, M. M., Colebatch, H. J. H., and Clarke, P. S. (1970). American

Review of Respiratory Diseases, 102, 236.
Sterling, G. M. (1968). Clinical Science, 34, 277.

Woolcock, A. J., and Read, J. (1965). Lancet, 2, 1323.

\title{
Gross Oedema in the Nephrotic Syndrome Treated with Frusemide in High Dosage
}

British Medical fournal, 1971, 1, 319-321

\section{Summary}

Five grossly oedematous patients with nephrotic syndrome required frusemide in doses of $250 \mathrm{mg} /$ day or more. Two cases needed albumin infusions to initiate the diuresis. As oedema was removed renal function improved in four cases. There were no side effects. It is concluded that frusemide in the high doses used is a safe and effective diuretic.

\section{Introduction}

The safety and potency of frusemide has been established by more than five years' clinical experience throughout the world (Wertheimer et al., 1967; Dollery, 1968). In the absence of severe renal failure a satisfactory diuretic response is usually obtained with daily doses of $\mathbf{4 0 - 2 0 0 ~} \mathrm{mg}$, but occasionally much higher doses are required (Muth, 1968; Heiland et al., 1969). The safety of administration of these larger amounts of frusemide has not been adequately established in patients without severe renal failure, and therefore a series of five

Charing Cross Hospital Medical School, Fulham Hospital, London W.6 P. D. SNASHALL, B.SC., M.R.C.P., Medical Registrar (Present address : Medical School, University of Southampton, 125 Tremona Road, Southampton) grossly oedematous nephrotic patients who were treated with more than $200 \mathrm{mg}$ of frusemide per day were studied.

\section{Patients and Methods}

Two women and three men aged 16 to 50 who had failed to respond to conventional doses of frusemide were studied (Table I). All had the nephrotic syndrome with gross oedema and hypoalbuminaemia (less than $1.5 \mathrm{~g} / 100 \mathrm{ml}$ in four cases) and more than $5 \mathrm{~g}$ of urinary protein loss per 24 hours. In all cases the glomerular filtration rate was below normal at the onset of treatment. All subjects were normotensive. The study was mainly retrospective, the criterion for selection being that these patients needed over $250 \mathrm{mg}$ of frusemide per day. All patients treated at this hospital in the past two years who satisfied this criterion were included.

Treatment was begun with $40-80 \mathrm{mg}$ of frusemide daily, but as none of the patients responded the dose was doubled, usually at daily intervals until the diuresis began. The dose was then varied according to the diuretic response, requirements tending to decrease as the oedema was removed. In two patients (Cases 1 and 4) who were uraemic the diuresis was established only after plasma volume expansion with salt-poor albumin, $25 \mathrm{~g}$ of which was diluted in 500 $\mathrm{ml}$ of water in one case and in mannitol $10 \%$ in the other, and given daily for one week. Frusemide was added to the infusion. Spironolactone or triamterene was given largely for the potassium-sparing properties. Potassium requirements 
TABLE I-Patients and Treatment

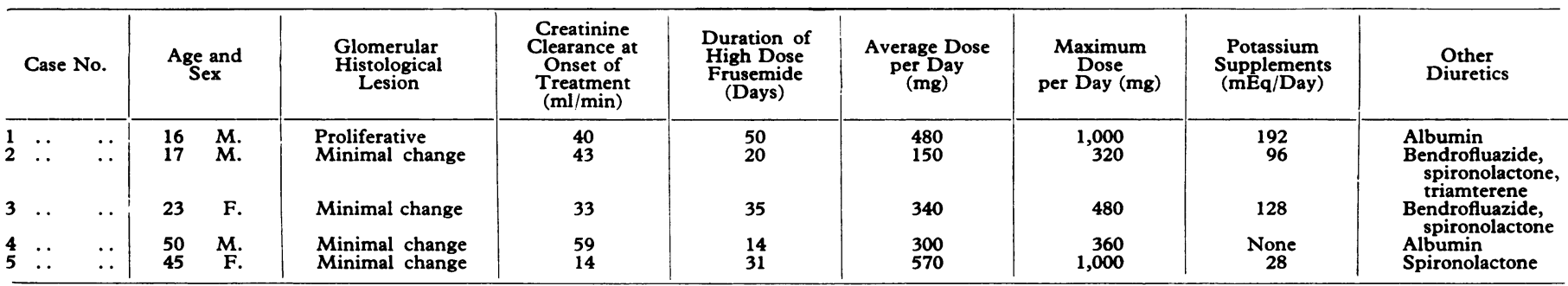

TABLE II-Results

\begin{tabular}{|c|c|c|c|c|c|c|c|c|c|c|}
\hline \multirow{2}{*}{$\begin{array}{l}\text { Case } \\
\text { No. }\end{array}$} & \multirow{2}{*}{$\begin{array}{c}\text { Total } \\
\text { Weight } \\
\text { Loss }(\mathbf{k g})\end{array}$} & \multicolumn{2}{|c|}{$\begin{array}{l}\text { Plasma Urea } \\
(\mathrm{mg} / 100 \mathrm{ml})\end{array}$} & \multicolumn{2}{|c|}{$\begin{array}{l}\text { Creatinine Clearance } \\
(\mathrm{ml} / \mathrm{min})\end{array}$} & \multicolumn{2}{|c|}{$\begin{array}{l}\text { Plasma Albumin } \\
(\mathrm{g} / 100 \mathrm{ml})\end{array}$} & \multicolumn{3}{|c|}{$\begin{array}{l}\text { Plasma Volume } \\
(131 \text { I H.S.A.) }\end{array}$} \\
\hline & & Before & After & Before & After & Before & After & Before & $\begin{array}{l}\text { After. } \\
\% \text { Change } \\
\text { in ( })\end{array}$ & Predicted \\
\hline $\begin{array}{ll}1 & \cdots \\
2 & \cdots \\
3 & \cdots \\
4 & \cdots \\
5 & \end{array}$ & $\begin{array}{l}16 \cdot 8 \\
19.5 \\
15 \cdot 5 \\
10.5 \\
26.7\end{array}$ & $\begin{array}{r}118 \\
96 \\
87 \\
150 \\
116\end{array}$ & $\begin{array}{r}62 \\
36 \\
70 \\
120 \\
54\end{array}$ & $\begin{array}{l}40 \\
43 \\
33 \\
59 \\
14\end{array}$ & $\begin{array}{l}78 \\
79 \\
39 \\
32 \\
67\end{array}$ & $\begin{array}{l}1 \cdot 1 \\
1.4 \\
1.4 \\
2 \cdot 3 \\
1.4\end{array}$ & $\begin{array}{l}0.9 \\
1 \cdot 3 \\
1.4 \\
3 \cdot 3 \\
3 \cdot 4\end{array}$ & $\begin{array}{l}2,000 \\
2,940 \\
1,740 \\
3,020 \\
2,530\end{array}$ & $\begin{array}{l}2,725(+31) \\
3,080(+5) \\
2,150(+24) \\
2,540(-15) \\
2,205(-15)\end{array}$ & $\begin{array}{l}2,650 \\
2,660 \\
2,130 \\
2,600 \\
2,580\end{array}$ \\
\hline
\end{tabular}

*Prediction based on dry weight from data of Nadler et al. (1962).

were assessed on the basis of the plasma potassium measured three times weekly, and always given as Slow- $K$, in which potassium chloride is held in a wax from which it is completely absorbed (de Wardener et al., 1969).

The patients were weighed daily. Plasma electrolytes and urea were estimated at least three times a week. Twiceweekly creatinine clearances were performed and protein excretion was measured. Once a week the midstream urine was examined and liver function and uric acid were estimated. Before diuresis the plasma volume was measured by dilution of ${ }^{131}$ I-labelled human serum albumin (H.S.A.), and this was repeated once the patient was oedema-free. The standard technique involved taking two separate plasma samples after equilibration. The rate of loss of albumin from the circulation, including renal losses, could thus be calculated and allowed for. All patients had a renal biopsy.

\section{Results}

The mean weight loss was $16.4 \mathrm{~kg}$ in a mean of 26 days (Table II). The highest dose of frusemide given was $1 \mathrm{~g} /$ day for 50 days (Case 1), but in this patient and in Case 4 a diuresis was not obtained until albumin was given with frusemide. In Case 1 the dose of frusemide was rapidly increased to $480 \mathrm{mg} /$ day, but his weight continued to rise and the blood urea remained stable around $120 \mathrm{mg} / 100 \mathrm{ml}$. The administration of a solution of $10 \%$ mannitol containing $25 \mathrm{~g}$ of albumin was associated with a rapid fall in weight by 11 $\mathrm{kg}$ in 10 days while the blood urea fell from 120 to 85 $\mathrm{mg} / 100 \mathrm{ml}$. A similar response was found in Case 4 (see Chart). Before being given albumin he was treated with frusemide in doses up to $200 \mathrm{mg} /$ day. For two weeks he received $80 \mathrm{mg}$ daily, during which period his weight fell by $8 \mathrm{~kg}$ but blood urea rose from 80 to $140 \mathrm{mg} / 100 \mathrm{ml}$. When his weight failed to drop further, the dose of frusemide was increased to $160 \mathrm{mg}$, but despite this his weight began to increase and his urea rose to $165 \mathrm{mg} / 100 \mathrm{ml}$. His weight continued to rise on $240 \mathrm{mg}$ of frusemide per day, but as soon as the course of albumin was started it fell by $10 \mathrm{~kg}$ in nine days while the urea fell from 168 to $110 \mathrm{mg} / 100 \mathrm{ml}$.

Potassium requirements as judged by the plasma levels varied from nil to $192 \mathrm{mEq} /$ day. A rise in uric acid was predictable (Lodwin and Guntow, 1965) but was not seen on treatment. Case 4 had a serum uric acid of $11.5 \mathrm{mg} / 100 \mathrm{ml}$ before any diuretic was given. No changes in the liver function tests were seen during frusemide administration.

As oedema was removed so renal function improved, except in Case 4, whose renal function subsequently returned to normal over a period of four weeks. When the patients were very oedematous their plasma volumes were all in the normal range, but subsequently when dry weight had been achieved the plasma volumes rose by 31 and $24 \%$ in two patients (Cases 1 and 3) whose initial plasma volumes were at the lower limit of normal, while in Cases 4 and 5 plasma volume fell by $15 \%$. There was no significant change of plasma volume in Case 2. Both patients whose plasma volumes fell during diuresis had a rise of plasma albumin, but in the other three albumin remained unchanged or fell during the course of treatment. Though Case 1 received albumin infusions to initiate diuresis, the second measurement of his plasma volume was performed more than three weeks after his last infusion of albumin, by which time he was oedema-free.

Of three renal biopsies (Cases 1, 3, and 5) performed after large doses of frusemide had been given, Cases 1 and 3 showed pronounced tubular atrophy, while in Case 5 tubular atrophy was only slight. Cases 2 and 4 had biopsies at an earlier stage in their illness before large amounts of frusemide had been given. Case 2 showed slight tubular atrophy, while

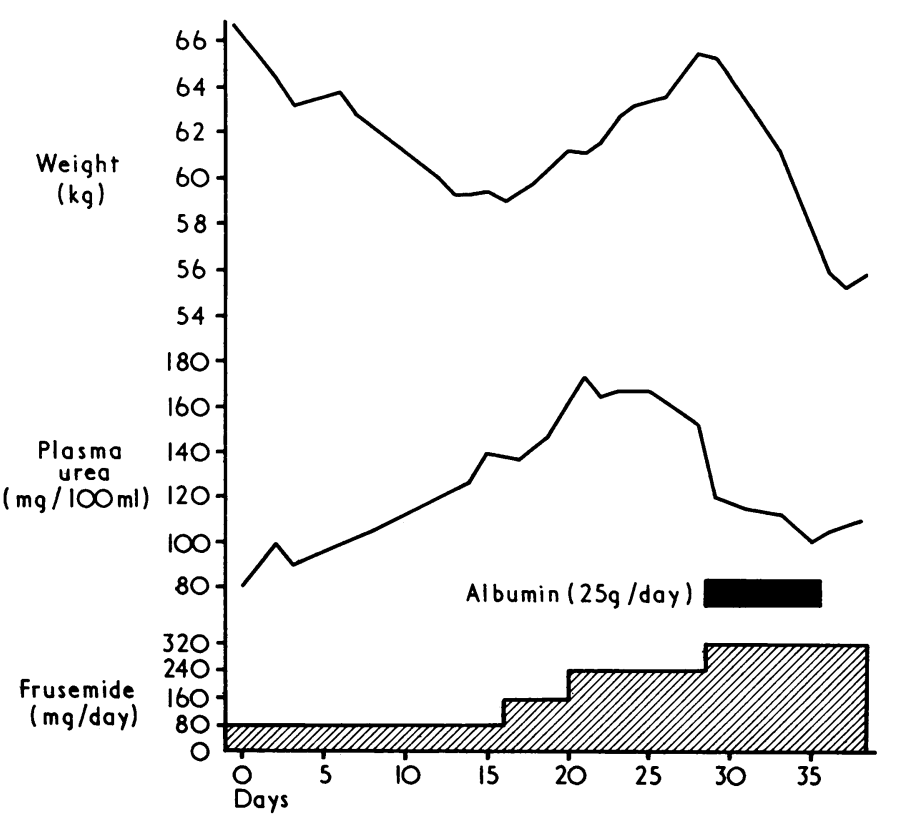

Case 4. Effect of frusemide and albumin on weight and plasma urea. 
the tubules were histologically normal in Case 4. Case 1 had proliferative glomerulonephritis, while in the other cases the glomeruli were normal on light microscopy.

\section{Discussion}

The above group of patients required more than the usual doses of frusemide to initiate and maintain a diuresis. Two patients referred from other hospitals had previously been labelled "frusemide resistant," having failed to respond to conventional doses of this diuretic. The results with this group of patients, however, confirm that frusemide is a diuretic whose great potency can be safely increased by exceeding the normally recommended doses. Such doses should be given only in hospital, with close observation of fluid balance and frequent monitoring of plasma electrolytes and renal function.

In patients suffering from congestive cardiac failure and respiratory failure given conventional doses of frusemide Jewkes et al. (1970) found that acute natriuresis is accompanied by a fall in extracellular water and plasma volume. Renal function deteriorates with a rise of blood urea and fall of glomerular filtration rate even though the plasma volume may still be within the normal range. By contrast four of the present series of nephrotic patients showed a definite improvement of renal function during diuresis despite enormous falls in extracellular fluid volume. Thus while Case 5 lost $26.7 \mathrm{~kg}$ in weight her creatinine clearance rose from 14 to $67 \mathrm{ml} / \mathrm{min}$ and her blood urea fell from 116 to $54 \mathrm{mg} / 100 \mathrm{ml}$ despite a high-protein diet. In a similar series of four very oedematous nephrotic patients (Silverberg and Kjellstrand, 1968) renal function did not deteriorate despite large and rapid loss of weight, and in one case there was a pronounced improvement of renal function. These authors suggest that the diuresis may improve renal function by reducing renal interstitial oedema, thus alleviating tubular obstruction.

The pronounced tubular atrophy seen on renal biopsy in two cases previously treated with large doses of frusemide raises the question of whether frusemide was the cause of this atrophy. Of course, poisoning with agents that cause tubular necrosis, such as carbon tetrachloride, ethylene glycol, or mercury bichloride, causes a deterioration in renal function leading to acute renal failure. By contrast four patients in this series showed an improvement of renal function following frusemide administration; and the fifth patient, whose renal function initially deteriorated, had histologically normal tubules. The patient with the most pronounced tubular atrophy (Case 1) had an improvement of creatinine clearance from 40 to $78 \mathrm{ml} / \mathrm{min}$ during frusemide administration. Tubular atrophy is a common histological finding in nephrotic syndrome without treatment with diuretics. The present study therefore lends no support to the view that frusemide is directly nephrotoxic.

The rise in plasma volumes seen after diuresis in Cases 1 and 3 is difficult to explain in the absence of a rise in serum albumin. Garnett and Webber (1967) described the changes in plasma volume produced by treatment in 14 nephrotic patients. Ten patients, four of whom had diuresis of more than $10 \mathrm{~kg}$, showed a fall of plasma volume, while four showed a rise of plasma volume that was in each case associated with $a$-rise of serum albumin that averaged $1.6 \mathrm{~g} / 100 \mathrm{ml}$. By contrast the serum albumin in Case 1 fell from 1.1 to $0.9 \mathrm{~g} / 100 \mathrm{ml}$, and in Case 3 remained steady at $1.4 \mathrm{~g} / 100 \mathrm{ml}$, while the plasma volume in Case 1 rose by $725 \mathrm{ml}$ and in Case 3 by $410 \mathrm{ml}$. The explanation for these changes may be connected with the raised interstitial fluid pressure that exists in extremely oedematous tissues.

Guyton $(1963,1965)$ studied interstitial fluid pressure in the presence of oedema in the dog. He found that as oedema increased from mild to moderate interstitial pressure remained around atmospheric pressure, but when the oedema became more severe and the skin was stretched tight then interstitial pressure rose steeply. In both Cases 1 and 3 oedema was severe and the skin was tight. It is reasonable to assume that if interstitial fluid pressure acts on the skin it will also act on the walls of blood vessels and may partially collapse the lower pressure capacitance vessels, the venules and veins. At any one time $60-80 \%$ of the blood volume is contained within these vessels (Landis and Hortenstine, 1950; Wiedeman, 1963). This reduction in volume of the capacitance system will, of course, be reversed once the interstitial fluid pressure is reduced by removal of oedema. As the interstitial pressure falls, so the veins will reopen and the plasma volume may increase.

It is concluded that in the high doses used frusemide is a safe and effective diuretic.

I would like to thank Professor H. E. de Wardener for his advice and for allowing me to study patients under his care. I am grateful to Dr. R. Jewkes for performing the isotopic studies and for his helpful criticism of this study. I would also like to thank Hoechst Pharmaceuticals for their help and encouragement.

\section{References}

de Wardener, H. E., Clarkson, E. M., and Ford, J. (1969). British Medical

Fournal, 4, 168.
Dollery, C. T. (1968). In Side Effects of Drugs, ed. L. Meyles and A.

Herxheimer, p. 216. Amsterdam, Excerpta Medica Foundation.

Garnett, E. S., and Webber, C. E. (1967). Lancet, 2, 798.

Guyton, A. C. (1963). Circulation Research, 12, 399.

Guvton, A. C. (1965). Circulation Research, 16, 452.

Heiland, A., Klutsch, K., Moormann, A., and Hennemann, H. (1969). Deutsche Medizinische Wochenschrift, 94, 1568.

Jewkes, R. F., Burki, N., and Guz, A. (1970). Clinical Science, 38, 439. Landis, E. M., and Hortenstine, J. C. (1950). Physiological Reviews, 30, 1. Lodwin, T. F., and Guntow, R. W. (1965). Canadian Medical Association Fournal, 93, 1296

Muth, R. G. (1968). Annals of Internal Medicine, 69, 249.

Nalder, S. B., Hidalgo, I. U., and Bloch, T. (1962). Surgery, 51, 244.

Silverberg, D. S., and Kjellstrand, C. M. (1968). Acta Medica Scandinavica,

$184,473$.
Wertheimer, L., Almondhiny, H., and Khero, B. (1967). Archives of Internal Medicine, 119, 189.

Wiedeman, M. P.'(1963). Circulation Research, 12, 375. 